\title{
SUBTYPING OF Campylobacter spp. STRAINS AND THEIR INCIDENCE IN PIGLETS
}

\author{
STEINHAUSEROVÁ, I., FOJTÍKOVÁ, K., MATIAŠOVIC, J.*
}

Department of Meat Hygiene and Technology, * Department of Animal Breeding and Genetics, Faculty of Veterinary Hygiene and Ecology, University of Veterinary and Pharmaceutical Sciences, Brno, Czech Republic

Received December 27, 2000

Accepted May 28, 2001

Abstract

Steinhauserová I., K. Fojtíková, J. Matiašovic: Subtyping of Campylobacter spp. Strains and Their Incidence in Piglets. Acta Vet. Brno 2001, 70: 197-201.

Campylobacter spp. are common cause of enteritis in humans, but the routes of transmission and the subtypes of these bacteria responsible for infection are not clearly known. Pigs, which are infected early in life, are known to be symptomless carriers of Campylobacter spp. We evaluated and subtyped 225 samples of rectal swabs from piglets with and without disease by polymerase chain reaction (PCR) and restriction fragment length polymorphism. Little difference was found in the presence of Campylobacter spp. in healthy and diseased piglets: Campylobacter sp. was found in $49 \%$ of 225 samples of rectal swabs from piglets with enteric disease, C. coli, C. jejuni and atypical strains representing $81 \%, 17 \%$ and $2 \%$, respectively, and in $41 \%$ of rectal swabs from healthy piglets, $C$. coli and $C$. jejuni representing $85 \%$ and $15 \%$, respectively. C. coli strains were subtyped from the PCR product with the HinfI restriction enzyme, and four subtypes were found and confirmed by sequencing. The most frequent were types III (46\%) and I (31\%), whereas type II was found in $6 \%$ of strains only, and $17 \%$ of strains had no cutting site (type IV). Thus, both healthy and sick piglets had a high incidence of Campylobacter spp., which might result in contamination of pork during slaughter. No link was demonstrated between the incidence of individual subtypes of $C$. coli and the frequency or severity of disease on pig farms.

Campylobacter coli, Campylobacter jejuni, typing, PCR-RFLP

Campylobacter jejuni and C. coli are among the most common causes of acute bacterial enteritic diseases in humans. Campylobacter spp. commonly occur in the normal intestinal flora of a number of domestic as well as wild animals, and regularly reported sources of Campylobacter spp. infections in humans include inadequately cooked poultry and crosscontamination of cooked food or water. Frequent sources of Campylobacter spp. include not only poultry but also pigs. Like poultry, adult pigs have Campylobacter spp. as a part of their intestinal microflora without exhibiting any symptoms of disease. These bacteria are found at relatively frequently in the intestinal contents of pigs in slaughterhouses, with incidences of up to $92 \%$ (Harvey et al. 1999), but varying from 0 to $60 \%$ (Svedhem et al. 1981, Oosterom et al. 1985).

C. jejuni, C. coli and other Campylobacter spp. are found relatively frequently in animals and in the environment, as well as in human infections (Oosterom et al. 1985). The occurrence of $C$. jejuni in pigs appears to be increasing. In the older literature (S vedhem et al. 1981; Oosterom et al. 1985), C. coli was described as the dominant species in pigs, while $C$. jejuni was reported in connection with poultry; however, recent reports indicate that although $C$. coli is still the predominant species, $C$. jejuni accounts for $30-50 \%$ of findings in both healthy and sick pigs (Harvey et al. 1999). Other Campylobacter spp. particularly $C$. lari and $C$. hyointestinalis, have been isolated in pigs only sporadically. We (Steinhauserová 1998) have found that the incidence of infection with Campylobacter

Address for correspondence:

Doc,. MVDr. Iva Steinhauserová, CSc.

Doc,.. MVDr. Iva Steinhauserová, CSc.
Department of Meat Hygiene and Technology

maceutical Sciences
Phone: 05-41562660

Fax: 05-41321230 
spp. among pigs on farms in the Czech Republic varies between 20 and $40 \%$ and that C. coli accounts for up to $90 \%$ of all strains isolated.

Colonization of the mucous membrane of piglet intestines occurs very early after birth. Because adult pigs carry Campylobacter spp., the pathogen is maintained in the environment and piglets come into contact with it very early in life. Harvey et al. (1999) found that intestinal colonization occurs 24-48 days after birth and that piglets 9-14 days of age may already excrete Campylobacter spp. It is not clear yet whether transmission is from faeces or associated with suckling. Weijetens et al. (1997) showed that 9 out of 10 sows carried Campylobacter spp. 1 week before farrowing, and up to $85 \%$ of piglets are infected with Campylobacter spp. during the first 4 weeks of life, with $\log _{10} 4.1 \mathrm{CFU} / \mathrm{g}$ of intestinal contents (Weijtens et al. 1993). The bacteria then survive throughout the animals' lifespan.

Epidemiological studies are needed to identify the routes and mechanisms by which Campylobacter spp. spread among animals, in order to design measures to limit or stop the spread (Svedhem and Kaijser 1981). Currently, only the species of isolated strains is identified, without more detailed description. Because Campylobacter strains differ in their pathogenicity and virulence, however, they must be subtyped for epidemiological purposes. The available typing techniques, including serotyping, phagotyping and biotyping, are neither suitable as routine procedures nor do they have the necessary discriminatory power. Therefore, various molecular-based genotyping techniques have been designed and tested.

The purpose of this study was to ascertain the incidence of Campylobacter sp. among piglets up to the age of 8 weeks and to subtype the $C$. coli strains by molecular methods.

\section{Materials and Methods}

Bacterial strains

A total of 225 samples of rectal swabs and intestinal mucous membrane from sick or dead piglets (up to 8 weeks of age) with clinical symptoms of enteritis and 75 samples from piglets without diarrhoea or other clinical symptoms of disease were examined. The samples were obtained in cooperation with the Department of Microbiology and Immunology, University of Veterinary and Pharmaceutical Sciences, Brno, from 23 farms in the Czech Republic in 1999, were transported in an Amies transport medium (CCM425, Oxoid Ltd, United Kingdom) and were tested for the presence of pathogenic agents within $48 \mathrm{~h}$ after collection.

Strains C. jejuni CCM 6212, C. coli CCM 6211, C. upsaliensis ATCC 43954 and C. lari CCUG 23947 were used as references.

Culture and biochemical tests

The specimens were inoculated directly and after enrichment (BHI broth CM225) onto CCDA selective medium (Campylobacter Blood-free Agar Base CM739) with CCDA supplement (SR155). The cultures were incubated in a micro-aerophilic atmosphere (Gas pack, BR 60) at $37^{\circ} \mathrm{C}$ for $48 \mathrm{~h}$. All the media were obtained from Oxoid Ltd, United Kingdom. The species were identifed with the oxidase test, by catalase production, natrium hippurate and indoxyl acetate hydrolysis, hydrogen sulfite production on TSI agar, nalidixic acid and cephalothin sensitivity tests and growth at 42,30 and $25^{\circ} \mathrm{C}$.

DNA extraction

Bacterial DNA was extracted by a slight modification of the method of Sambrook et al. (1989). Briefly, colonies identified as Campylobacter spp. were suspended in Tris-HCl-EDTA buffer, $\mathrm{pH}$ 8.00, frozen and thawed repeatedly and digested with proteinase $\mathrm{K}$ at $37{ }^{\circ} \mathrm{C}$. The DNA released was purified by extraction with phenol:chloroform:isoamylalcohol (Serva, Germany) and chloroform and then precipitated with absolute ethanol. The DNA pellet was dissolved in $40 \mathrm{ml}$ of Tris-Hcl- EDTA buffer and stored at $-20^{\circ} \mathrm{C}$.

Polymerase chain reaction

All strains classified biochemically as Campylobacter spp. were tested by the polymerase chain reaction (PCR). The CJF1 and CJF2 oligonucleotide primers from the flagelline A gene sequences (fla A) described by Itoh et al. (1995) were used. The assumed length of the product was 410 base pairs.

The reaction mixture $(25 \mu 1)$ contained $10 \mathrm{mmol}^{-l^{-1}}$ Tris- $\mathrm{HCl}\left(\mathrm{pH} 9.0\right.$ at $\left.25^{\circ} \mathrm{C}\right), 50 \mathrm{mmol} . \mathrm{l}^{-1} \mathrm{KCl}, 1.5 \mathrm{mmol} . \mathrm{l}^{-1}$ $\mathrm{MgCl}_{2}, 0.1 \%$ Triton X-100, $200 \mu$ mol. $1^{-1}$ each of the deoxynucleotides dATP, dCTP, dGTP and dTTP, $20 \mu \mathrm{mol}^{-1}$ each of CJF1 and CJF2 primers (Sigma-Aldrich, USA), $1.25 \mathrm{U}$ of Taq polymerase (Promega, USA) and $1 \mu \mathrm{g}$ of template DNA, made up to a final volume of $25 \mu 1$ with water. PCR amplification was performed in a 200PTC 
thermocycler (MJ Research, USA) under the following conditions: $94{ }^{\circ} \mathrm{C}$ for $4 \mathrm{~min}, 30$ cycles at $94{ }^{\circ} \mathrm{C}$ for $1 \mathrm{~min}, 57$ ${ }^{\circ} \mathrm{C}$ for $1 \mathrm{~min}, 72^{\circ} \mathrm{C}$ for $30 \mathrm{~s}$ and final amplification at $72{ }^{\circ} \mathrm{C}$ for $10 \mathrm{~min}$. A negative control with no template DNA was prepared. After cycling, the products were visualized by electrophoresis $\left(12{\left.\mathrm{~V} . \mathrm{cm}^{-1}\right)}^{-1}\right.$ a $1.5 \%(\mathrm{w} / \mathrm{v})$ agarose gel (Serva, Germany) with 1 g..$^{-1}$ ethidium bromide. pUC/Hae III (Sigma, USA) was used as the molecular-size marker.

PCR-restriction fragment length polymorphism (RFLP) was used for differentiation of thermophilic Campylobacter spp. The PCR-RFLP reaction mixture contained $4 \mu$ lof PCR product and $1 \mathrm{U}$ of restriction enzyme HinfI (TaKaRa, Japan) and was made up to a final volume of $20 \mathrm{ml}$. The reaction mixture was incubated at $37^{\circ} \mathrm{C}$ overnight, and the products were analysed on polyacrylamide gel (FMC BioProducts, USA).

Sequencing of amplified products

Restriction sites on C. coli for Hinf I were confirmed by sequencing, and four strains representing the RFLP types found were selected. The Original TA Cloning® Kit (Version G, Invitrogen, USA) was used for cloning. After checking the amplification on agarose gel, DNA was ligated with Topo TA vector, which was then used to transform the Top 10 F' cells. The transformed cells were placed on Petri containing Luria-Bertoni agar, ampicillin $\left(100 \mu \mathrm{g} . \mathrm{ml}^{-1}\right)$ and a mixture of X-gal and IPTG and incubated at $37^{\circ} \mathrm{C}$ for $16-20 \mathrm{~h}$. After incubation, four white colonies with an insert were placed in Luria-Bertoni broth and incubated for $16 \mathrm{~h}$. Plasmids were isolated from a portion of the cells by rapid alkaline lysis. Positive transformants were further confirmed according to the size of split inserts on agarose gel. Plasmids for sequencing were isolated with the Qiagen Plasmid Mini Kit.

The sequences of the two DNA chains were ascertained on an ABI PRISM 310, Version 3.0 (Perkin Elmer, USA).

\section{Results}

We identified Campylobacter spp. in 111 of 225 samples from sick piglets (49\%). Biochemical typing showed that 90 were $C$. coli strains (81\%), and 19 were $C$. jejuni $(17 \%)$, of which 18 strains were typed as $C$. jejuni susp. jejuni and one as $C$. jejuni subsp. doylei. Two of the isolated strains could not be identified by biochemical methods. In the set of 75 samples from piglets with no clinical signs of disease, the incidence of Campylobacter sp. was $41 \%$, comprising 31 strains, 26 of which (85\%) were identified as C. coli and 5 as C. jejuni (Table 1).

Table 1

Occurrence of thermophilic Campylobacter spp. in piglets

\begin{tabular}{|l|c|c|c|c|}
\hline \multirow{2}{*}{} & \multicolumn{2}{|c|}{ Piglets with enteritis } & \multicolumn{2}{c|}{ Piglets without enteritis } \\
\cline { 2 - 5 } & No. & $\%$ & No. & 85 \\
\hline C. coli & 90 & 81 & 26 & 15 \\
C. jejuni subsp. jejuni & 18 & 17 & 5 & 100 \\
C. jejuni subp. doylei & 1 & & 0 & 0 \\
Atypical strains & 2 & 100 & 31 & \\
Total & 111 & & & \\
\hline
\end{tabular}

The $C$. coli strains isolated by the PCR reaction were cut with the HinfI restriction enzyme and classified into one of four groups according to the size of the fragments obtained (Fig. 1). Type I strains contained restriction site A with fragments of 100 and $310 \mathrm{bp}$, and type II strains contained restriction site $B$ with fragments of 145 and $265 \mathrm{bp}$. Type III strains had both $\mathrm{A}$ and $\mathrm{B}$ restriction sites and were cut to fragments of 100, 45 and $265 \mathrm{bp}$. Type IV strains contained neither restriction site, and the PCR product (410 bp) was not cut (Plate XI, Fig. 2).

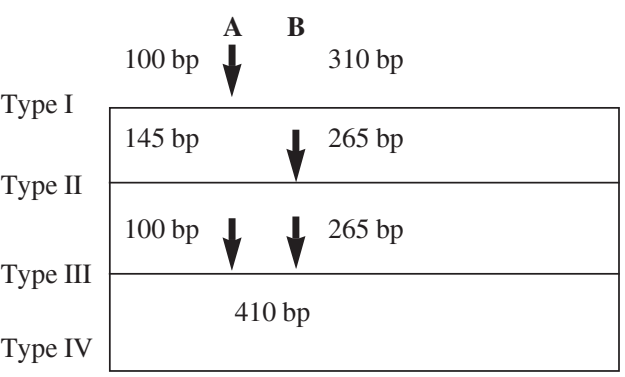

Fig. 1. PCR-RFLP patterns of Campylobacter coli observed with $H$ infl 
The groups of $C$. coli strains were not of equal size: the most frequent was type III (46\%), with two cutting sites. The A site (type I) was found in $31 \%$ of strains and the B site (type II) in $6 \%$ of strains; only $17 \%$ of $C$. coli strains (type IV) were not digested with Hinfl restrictase.

No relationship was found between the incidence of a specific type and the frequency of infection on the farms. Usually one, or at most two, types of $C$. coli were identified on each farm. In the case of repeated samplings, however, another type or a different frequency of the two types was usually found.

\section{Discussion}

The incidence of Campylobacter spp. was $49 \%$ in the 225 samples from sick piglets and $41 \%$ in the samples from piglets without clinical signs of disease. C. coli was the most frequent species in both sick and healthy piglets, representing $81 \%$ and $85 \%$ of samples, respectively.

Evaluation of the incidence of the various types of $C$. coli on different farms showed no relationship between the number of sick piglets and the prevalent subtype of $C$. coli. A wide diversity among isolated strains of Campylobacter spp. was also reported by Weitens et al. (1997), who demonstrated the existence of identical subtype profiles in sows and piglets, which seems to support the assumption of maternal transmission of Campylobacter spp. Similar subtyping profiles were not found, however, among Campylobacter strains isolated on different farms.

We used the flagellin A part of the gene, as flagellin genes have already been sequenced, and all studies point to the presence of two (fla $A$ and fla $B$ ), positioned in tandem. These genes appear to be sufficiently conserved to be good candidates for genotyping (Guerry et al. 2000). On the basis of information obtained from the gene bank, we assumed that cutting with HinfI restrictase would produce one cutting position $(278 \mathrm{bp})$ that would be specific to C. coli and another cutting position (100 bp) in other strains. Our preliminary results show, however, that the cut was not specific to $C$. coli and that there are one or two cutting positions elsewhere (145 bp and $100 \mathrm{bp}$ ). DNA sequencing of $C$. coli samples also confirmed the division into four types, while failing to provide proof of the existence of a cutting position at $278 \mathrm{bp}$.

As $C$. coli and $C$. jejuni occur normally in the intestinal content of pigs without clinical symptoms, it is evident that pigs represent a possible source of human infection with Campylobacter spp. Both healthy and sick piglets had a high incidence of Campylobacter spp., which might result in contamination of pork during slaughter. The high incidence rate of $C$. coli indicates the importance of subtyping. No link was demonstrated between the incidence of individual subtypes of $C$. coli and the frequency or severity of disease on pig farms.

\section{Incidence a subtypizace kmenů Campylobacter sp. izolovaných od selat}

Campylobacter sp. je častou příčinou enteritid u člověka, ale cesty přenosu nejsou dosud zcela spolehlivě objasněny. Jedním z častých nositelů Campylobacter sp. jsou i prasata, jejichž střevo bývá kolonizováno Campylobacter sp. již brzy po narození. Bylo hodnoceno 225 vzorků rektálních výtěrů selat s výskytem průjmů i bez klinických příznaků. Byly zjištěny jen malé rozdíly mezi nálezy Campylobacter sp. u klinicky zdravých a nemocných selat. Ze vzorků rektálních výtěrů selat trpících enteritidami byl zjištěn výskyt Campylobacter sp. u 49 \%, z toho tvořil Campylobacter coli 81\%, Campylobacter jejuni $17 \%$ a $2 \%$ byly atypické kmeny. Z rektálních výtěrů zdravých selat byla zjištěna incidence $41 \%$ Campylobacter sp.; z toho $85 \%$ Campylobacter coli a $15 \%$ Campylobacter jejuni. 
U kmenů Campylobacter coli byla provedena subtypizace štěpením PCR (polymerase chain reaction) produktu restrikčním enzymem HinfI. Byly zjištěny a sekvenováním potvrzeny 4 subtypy C. coli. Nejvyšší frekvence byla u typu III (46\%) a I (31 \%). Typ II se vyskytoval jen u 6\% kmenů a $17 \%$ kmenů nemělo žádné štěpné místo (typ IV). Při hodnocení výskytu jednotlivých subtypů $C$. coli na farmách nebyla zjištěna vazba výskytu určitého typu na frekvenci nebo průběh onemocnění. Klinicky zdravá a nemocná selata jsou zdrojem Campylobacter sp. a může docházet ke kontaminaci svaloviny během porážení prasat.

\section{Acknowledgements}

This study was supported by Ministry of Education, Youth and Sports of the Czech Republic, grant No. 162700005 .

\section{References}

GUERRY, P., ALM, R., SZYMANSKI, CH., TRUST, T. J. 2000: Structure, function, and antigenicity of Campylobacter flagella. In: NACHAMKIN, I., BLASER, M. J. (Eds.), Campylobacter. ASM Press, Washington DC, pp. 405-423

HARVEY, R.B., YOUNG, C. R., ZIPRIN, R. L., HUME, M. E., GENOVESE, K. J., ANDERSON, R. C., DROLESKEY, R. E., STANKER, L. H., NISBET, D. J. 1999: Prevalence of Campylobacter spp. isolated from the intestinal tract of pigs raised in an integrated swine production system. J. Am. Vet. Med. Assoc. 215:16011604

ITOH, R., SAITOH, S., YATSUYANA,G. I. J. 1995: Specific detection of Campylobacter jejuni by means of polymerase chain reaction in chicken litter. J. Vet. Med. Sci. 57:125-127

OOSTEROM, J., DEKKER, R., DE WILDE, G. J. A. 1985: Prevalence of Campylobacter jejuni and Salmonella during pig slaughtering. Vet. Q. 7: 31-34

SAMBROOK, J., FRITSCH, E. F., MANIATIS, T. 1989: In: Molecular cloning: A laboratory manual, $2^{\text {nd }}$ ed. Cold Spring Harbor, New York: Cold Spring Harbor Laboratory. 352 p.

STEINHAUSEROVÁ, I. 1998: Campylobacter $\mathrm{sp}$. v prostředí a v potravinách živočišného původu. Ed. LAST Brno, $110 \mathrm{p}$.

SVEDHEM, A, KAIJSER, B. 1981: Isolation of Campylobacter jejuni from domestic animals and pets: Probable origin of human infection. J. Infect. 3: 37-40

WEIJTENS, M. J. B. M., BIJKER, P.G. H., VAN DER PLAS, J., URLINGS, H. A. P., BIESHEUVEL, M. H. 1993 : Prevalence of Campylobacter in pigs during fattening; an epidemiological study. Vet. Q. 15:138-43

WEIJTENS, M. J. B. M, VAN DER PLAS, J., BIJKER, P.G. H, URLINGS, H A. P., KOSTER, D, VAN LOGTESTIJN, J. G., HUIS IN'T VELD, J. H. J. 1997: The transmission of Campylobacter in piggeries; an epidemiological study. J. Appl. Microbiol. 83: 693-69 
Plate XI

Steinhauserová I. et al.: Subtyping... pp. 197-201

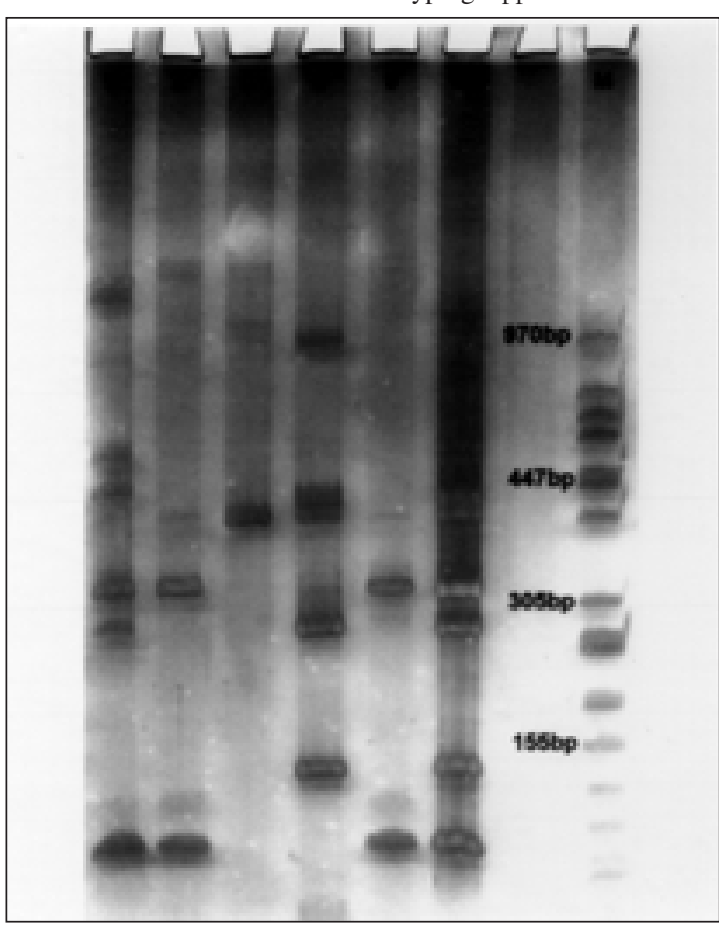

Fig. 2. RFLP analysis of PCR products. Line 1, type III (265, 100, $45 \mathrm{bp})$; line 2, type III (265, 100, $45 \mathrm{bp})$; line 3 , type IV (410 bp); line 4, type II (265, 145 bp); line 5, type I ( 310,100 bp); line 6, type III ( $265,100,45$ bp); M, marker (TopBio) 